have a cost, and this cost should be known to those involved in the budgeting process. ${ }^{26}$

\section{REFERENCES}

1. Jagger J, Hunt EH, Brand-Elnaggar J, Pearson RD. Rates of needle-stick injury caused by various devices in a university hospital. $N$ Engl J Med 1988;319:284-288.

2. Ribner BS, Landry MN, Gholson GL, Linden LA Impact of a rigid puncture resistant container system upon needlestick injuries. Infect Control 1987;8:63-66.

3. Krasinski K, LaCouture R, Holzman RS. Effect of changing needle disposal system on needle puncture injuries. Infect Control 1987;8:59-62.

4. Edmond M, Khakoo R, McTaggart B, Solomon R. Effect of bedside needle disposal units on recapping frequency and needlestick injury. Infect Control Hosp Epidemiol 1988;9:114-116.

5. Jagger J, Pearson RD, Brand JJ. Avoiding the hazards of sharp instruments. Lancet 1986;1:1274.

6. McCormick RD, Meisch MG, Ircink FJ, Maki DG. Epidemiology of hospital sharps injuries: a 14-year prospective study in the pre-AIDS and AIDS eras. Am J Med 1991;91(3B):301S-307S.

7. O'Neill TM, Abbott AV, Radecki SE. Risk of needlesticks and occupational exposure among residents and medical students. Arch Intern Med 1992;152:1451-1456.

8. Berry AJ, Greene ES. The risk of needlestick injuries and needlesticktransmitted diseases in the practice of anesthesiology. Anesthesiology 1992;77:1007-1021.

9. Klontz KC, Gunn RA, Caldwell JS. Needlestick injuries and hepatitis B immunization in Florida paramedics: a statewide survey. Ann Emerg Med 1991;20:1310-1313.

10. Mitsui T, Iwano K, Masuka K, Yamazaki C, Okamoto H, Tsuda F, et al. Hepatitis $\mathrm{C}$ virus infection in medical personnel after needlestick accident. Hepatology 1992;16:1109-1114.

11. Kiyosawa K, Sodeyama T, Tanaka E, Nakano Y, Furuta S, Nishioka K, et al. Hepatitis C in hospital employees with needlestick injuries. $A n n$ Intern Med 1991;115:367-369.

12. Cardo DM, Culver DH, Ciesielski CA, Srivastava PU, Marcus R, Abiteboul D, et al. A case-control study of HIV seronconversion in health care workers after percutaneous exposure. Centers for Disease Control and Prevention Needlestick Surveillance Group. $N$ Engl $J$ Med 1997;337:1485-1490.

13. Anderson DC, Blower AL, Packer JM, Ganguli LA. Preventing needlestick injuries. $B M J 1991 ; 302: 769-770$.

14. Abiteboul D, Antona D, Bonnet N, Dagon C, Domart M, Florentin A, et al. Surveillance des accidents du travail avec exposition au sang à l'Assistance Publique-Hópitaux de Paris. Arch Mal Prof 1994;55:1-8.

15. Ministère de l'emploi et de la Solidarité. Circulaire DGS/DH/98/249 du 20 avril 1989 relative à la prévention de la transmission d'agents infectieux véhiculés par le sang ou les liquides biologiques lors des soins dans les établissements de santé. Paris, France: Ministère de l'emploi et de la Solidarité.

16. Drummond M, Stoddart G, Torrance G. Methods for Economic Evaluation of Health Care Programmes. Oxford, UK: Oxford University Press; 1989:71-84.

17. Jagger J, Hunt EH, Pearson RD. Recapping used needles: is it worse than the alternative? I Infect Dis 1990;162:784-785.

18. Needlesticks: preaching to the seroconverted? Lancet 1992-340:640-642.

19. Cummins AJ, Tedder RS. Inadequate information on needlesticks accidents. Lancet 1992;339:1178-1179.

20. Dodging the needle in health care. Science 1992;258:34

21. Beekman SE, Vlahov D, Koziol DE, McShalley ED, Schmitt JM, Henderson DK. Temporal association between implementation of Universal Precautions and a sustained, progressive decrease in percutaneous exposures to blood. Clin Infect Dis 1994;18:562-569.

22. Adal K, Anglim AM, Palumbo CL, Titus MG, Coyner BJ, Farr BM. The use of high-efficiency particulate air-filter respirators to protect hospital workers from tuberculosis. A costeffective analysis. $N$ Engl J Med 1994;331:169-173.

23. Hamory $\mathrm{BH}$. Underreporting of needlestick injuries in a university hospital. Am J Infect Control 1983;11:174-177.

24. Yassi A, McGill ML, Khokhar JB. Efficacy and cost-effectiveness of a needleless intravenous access system. Am I Infect Control 1995;23:5764.

25. Laufer FN, Chiarello LA. Application of cost-effectiveness methodology to the consideration of needlestick-prevention technology. Am J Infect Control 1994;22:75-82.

26. Tengs TO, Adams ME, Pliskin J, Safran DG, Siegel JE, Weinstein MC, et al. Five-hundred life-saving interventions and their cost-effectiveness. Risk Anal 1995;15:369-390.

\title{
Bloodstream Infections Associated With Needleless Devices
}

\section{Gina Pugliese, RN, MS Martin S. Favero, PhD}

More patients are being treated at home with therapies traditionally administered by trained personnel. One of these treatments, home infusion therapy, is the most rapidly growing area of home health care. Because these treatments are typically given by the patient or family members, who have little or no training in infection control, the risk of infection increases.

The influence of infection control practices on bloodstream infection (BSI) risk was examined in a home healthcare setting in which three needleless devices were used consecutively. A case-control study and a retrospective cohort study were conducted. Risk factors for BSI included lower education level, younger age, having a central venous catheter
(CVC) with multiple ports, or having a tunneled CVC.

Among patients with a tunneled CVC, those at greatest risk had been allowed to shower rather than bathe and to get their exit site wet $(P<.01)$. The investigators suggested that this was due to leniency with water exposure and sterile technique in these patients. Specifically, patients with tunneled CVCs were permitted to shower and to change the dressing during showering. In contrast, patients with other catheter types were instructed to bathe, not shower, and to change dressings using sterile techniques (sterile gloves and, optionally, masks).

A high proportion (49\%) of isolates were hydrophilic gram-negative bacteria, rather than gram-positive cocci colonizing the skin, suggesting exposure to tap water was related to the increased risk of infection. In the cohort study, the BSI rate decreased as the frequency of changing the needleless-device end cap increased from once weekly up to every 2 days, suggesting that the mechanism for BSI may involve contamination from the end cap; the longer the end cap was in place, the more likely microorganisms were to reach the intravascular segment of the catheter.

This study demonstrates the need to establish systematic surveillance in home healthcare systems and to educate home caregivers in infection control practices, especially when introducing new techniques and procedures to this population.

FROM: Do AN, Ray BJ, Banerjee $\mathrm{SN}$, Illian AF, Barnett BJ, Pham MH, et al. Bloodstream infection associated with needleless device use and the importance of infection-control practices in the home health care setting. $J$ Infect Dis 1999;179:442-448. 